\title{
Citotoxicity of Fipronil on Hepatocytes Isolated from Rat and Effects of Its Biotransformation
}

\author{
Marieli Guelfi ${ }^{1}$, Marcos Antonio Maioli ${ }^{2}$, Marco Aurélio Tavares ${ }^{1}$ and Fábio Erminio \\ Mingatto $^{1^{*}}$ \\ ${ }^{I}$ Departamento de Zootecnia, Universidade Estadual Paulista ; Dracena - SP - Brasil. ${ }^{2}$ Produção e Saúde Animal; \\ Universidade Estadual Paulista; Araçatuba - SP - Brasil
}

\begin{abstract}
The aim of this study was to characterize the mechanism of toxicity of fipronil on hepatocytes isolated from the rat and the effect of its biotransformation on the toxicological potential. The toxicity of fipronil was assessed by monitoring the oxygen consumption and mitochondrial membrane potential, intracellular ATP concentration, Ca ${ }^{2+}$ homeostasis and cell viability. The cell viability was evaluated by trypan blue exclusion in hepatocytes that were isolated from the normal rats and by the release of the enzymes alanine transaminase and aspartate transaminase in hepatocytes that were isolated from the normal rats or proadifen-pretreated rats. Fipronil reduced mitochondrial respiration in the cells that were energized with glutamate plus malate in a dose-dependent manner and dissipated the mitochondrial membrane potential that was accompanied by a reduction in ATP concentration and a disruption of intracellular $\mathrm{Ca}^{2+}$ homeostasis. The cell viability was affected by fipronil with higher potency in hepatocytes that were isolated from the normal rats, which indicated that the metabolism of this insecticide increased its toxicological potential. The results of this study indicated that the toxicity of fipronil to the hepatocytes was related to the inhibition of mitochondrial activity, which led to decreased ATP synthesis and a consequent alteration in intracellular $\mathrm{Ca}^{2+}$ homeostasis and ultimately resulted in cell death.
\end{abstract}

Key words: fipronil, hepatotoxicity, bioenergetics, biotransformation, calcium homeostasis

\section{INTRODUCTION}

Fipronil is an insecticide that is widely used to control various pests, such as cockroaches, mosquitoes, locusts, fleas, lice and ticks in the dogs, cats and cattle (Chaton et al. 2002; Aajoud et al. 2003). This insecticide belongs to the new generation of insecticides that have been developed to reduce the damage to the environment and mammals. These new insecticides have been used as alternative control agents because some insects have developed resistance to the compounds, such as organophosphates, carbamates and pyrethroids.
These new insecticides have shown great efficacy at lower doses compared with the aforementioned agents (Bobe et al. 1997).

The toxic action of fipronil is due to its ability to act on the $\gamma$-aminobutyric acid receptor and noncompetitive blockers of chloride channels, which leads to the death of the insect by neuronal hyperexcitation and paralysis (Zhao 2004). There are three main routes for fipronil poisoning: oral, dermal and inhalation (Jennings et al. 2002; Fung et al. 2003). In the first case, fipronil does not represent a serious toxic agent to the mammals; however, anyone can be affected if the dose is higher than that recommended by the

*Author for correspondence: fmingatto@dracena.unesp.br 
manufacturers. According to the literature, cases of poisoning have occurred due to accidental exposure or misuse of the products containing fipronil (Chodorowski and Anand 2004; Lee et al. 2010). A case of acute poisoning after the ingestion of a high dose of fipronil has caused human death (Mohamed et al. 2004).

The central nervous system and other organs, including the liver, can be affected by the treatment with fipronil. A study by Silva (2008) evaluated the effects of the prolonged exposure of the rats to the insecticide; swollen hepatocytes and increased liver weights were observed in the animals that were treated with an oral dose of 10 $\mathrm{mg} \mathrm{kg}$ body weight ${ }^{-1}$, which corresponded to one tenth of the $\mathrm{LD}_{50}$ value established for the rats (Tingle et al. 2003). In addition, the livers from the rats that were evaluated after exposure to different concentrations of fipronil $(15,25$ and 50 $\mathrm{mg} \mathrm{kg}$ body weight $^{-1}$ ) revealed cytological, morphological and immunohistochemical changes in the hepatocytes with autophagic processes, steatosis and necrotic cell death (Oliveira al. 2012).

Once in the blood, fipronil and its metabolites are widely distributed, particularly in adipose tissues, and have a high level of enterohepatic recirculation (Hainzl and Casida 1996; Mohamed et al. 2004). The formation of the sulfone metabolite, which is derived from an oxidation reaction of the thioether group, corresponds to the primary route of hepatic metabolism of the compound (Caboni et al. 2003; Tang et al. 2004). According to Leghait et al. (2009), this oxidation is catalyzed by cytochrome P450 coenzymes, principally CYP3A4. Both fipronil and its sulfone metabolite induced cell death in HepG2 cells and human hepatocytes (Das et al. 2006).

The liver performs many functions, including animal metabolism receiving nutrients as well as xenobiotics, which are absorbed through the digestive tract and the portal vein (Guillouzo 1998). The xenobiotic metabolism in the liver is accomplished by cytochrome P450, and its main function is to increase the polarity of these substances; therefore, excretion occurs more easily (Oga 2008). However, this process is responsible for the toxic effects of numerous chemical compounds. Metabolites may cause adverse effects in the animal (Ioannides and Lewis 2004; Mingatto et al. 2007; Maioli et al. 2011) by changing a fundamental cellular component (mitochondria, for example) at the cellular and molecular levels, thus modulating its function (Meyer and Kulkarni 2001).

Due to the important functions of the liver in the animals and previous studies that indicated the occurrence of liver damage after the use of fipronil, this study aimed to characterize the mechanisms of fipronil toxicity on parameters that were related to bioenergetics and cell death and to determine whether the toxicity that was induced by the compound was due to a possible activation following its metabolism in the liver.

\section{MATERIAL AND METHODS}

\section{Chemicals}

Fipronil (96.6\% purity) was kindly provided by the Ourofino Agribusiness (Cravinhos, SP, Brazil). Proadifen was purchased from SigmaAldrich (St. Louis, MO, USA), and sodium pentobarbital was purchased from Cristália (Itapira, SP, Brazil). All other reagents were of the highest commercially available grade. Fipronil and proadifen were dissolved in anhydrous dimethyl sulfoxide (DMSO). All stock solutions were prepared using glass-distilled deionized water.

\section{Animals}

Male Wistar rats, aged 7-8 weeks and weighing approximately $200 \mathrm{~g}$ were used in this study. The animals, which were obtained from the Central Bioterium of UNESP - Univ Estadual Paulista, Campus de Botucatu, SP, Brazil, were maintained with a maximum of four rats per cage under standard laboratory conditions with water and food provided ad libitum. The experimental protocols were approved by the Ethical Committee for the Use of Laboratory Animals of the UNESP - Univ Estadual Paulista, Campus de Dracena, SP, Brazil.In some experiments, the rats were pretreated with proadifen $(25 \mathrm{mg} \mathrm{kg}$ body weight $^{-1}$ ), a cytochrome $\mathrm{P} 450$ inhibitor, intraperitoneally for three consecutive days (Somchit et al. 2009).

\section{Isolation and incubation of hepatocytes}

For the surgical procedure, the rats were anesthetized by an intraperitoneal injection of sodium pentobarbital $\left(50 \mathrm{mg} \mathrm{kg}\right.$ body weight $\left.{ }^{-1}\right)$. The hepatocytes were isolated by a collagenase perfusion of the liver as previously described (Guguen-Guillouzo 1992). The hepatocyte viability after isolation was determined by Trypan 
blue $(0.16 \%)$ uptake, and the initial cell viability in all of the experiments was more than $85 \%$. The hepatocytes were suspended in Krebs-Henseleit buffer, $\mathrm{pH} 7.4$, containing $12.5 \mathrm{mM}$ HEPES and $0.1 \%$ bovine serum albumin (BSA) and maintained at $4^{\circ} \mathrm{C}$. The cells $\left(1 \times 10^{6} \mathrm{~mL}^{-1}\right)$ were incubated in $25-\mathrm{mL}$ Erlenmeyer flasks that were maintained under constant agitation $(30 \mathrm{rpm})$ at $37^{\circ} \mathrm{C}$ under a $95 \% \mathrm{O}_{2}$ and $5 \% \mathrm{CO}_{2}$ atmosphere. The reactions in the experiments of cell viability and cellular ATP content were initiated by the addition of fipronil at concentrations of $25,50,75$ and $100 \mu \mathrm{M}$. Aliquots $(1.0 \mathrm{~mL})$ of the suspension were removed from the mixture at appropriate times to determine cell death and biochemical parameters.

\section{Oxygen uptake}

Oxygen uptake by the isolated hepatocytes was monitored using a Clark-type oxygen electrode (Strathkelvin Instruments Limited, Glasgow, Scotland, UK). The respiration buffer contained $250 \mathrm{mM}$ sucrose, $2 \mathrm{mM} \mathrm{KH}_{2} \mathrm{PO}_{4}, 10 \mathrm{mM}$ HEPES, $\mathrm{pH} 7.2,0.5 \mathrm{mM}$ EGTA, $0.5 \%$ BSA, and $5 \mathrm{mM}$ $\mathrm{MgCl}_{2}$ at $37^{\circ} \mathrm{C}$. The cells were treated with $0.002 \%$ digitonin, and the state 3 and state 4 mitochondrial respiration rates were measured in the presence of $2 \mathrm{mM} \mathrm{ADP}$ and $1.0 \mu \mathrm{gmL}^{-1}$ oligomycin, respectively (Moreadith and Fisckum 1984). Fipronil at concentrations of 25, 50, 75 and $100 \mu \mathrm{M}$ was added to the medium immediately after the initiation of state 3 or state 4 respiration.

\section{Mitochondrial membrane potential}

The mitochondrial membrane potential was determined spectrofluorimetrically (Fluorescence Spectrophotometer, RF-5301PC, Shimadzu, Tokyo, Japan) by monitoring the fluorescence changes of rhodamine 123, a cationic fluorophore that is distributed in the matrix in response to the negative charge of the inner mitochondrial membrane (Lemasters et al. 1987) using as wavelengths of excitation and emission 505 and $535 \mathrm{~nm}$, respectively. Cells $\left(1 \times 10^{6}\right)$ were permeabilized with $0.007 \%$ digitonin and incubated in medium containing $250 \mathrm{mM}$ sucrose, $2 \mathrm{mM} \mathrm{KH}_{2} \mathrm{PO}_{4}, 10 \mathrm{mM}$ HEPES, $\mathrm{pH} 7.2,0.5 \mathrm{mM}$ EGTA, $1 \%$ BSA and $5 \mathrm{mM} \mathrm{MgCl}_{2}$ plus $1 \mu \mathrm{M}$ rhodamine 123 (2.0 $\mathrm{mL}$ final volume), and the energization of mitochondria was performed by adding $5 \mathrm{mM}$ glutamate plus $5 \mathrm{mM}$ malate. The results are expressed as a percentage of the fluorescence intensity over the control.

\section{Cellular ATP content}

The cellular ATP content was determined by the firefly luciferin-luciferase assay. The cell suspension was centrifuged at $50 \mathrm{~g}$ for $5 \mathrm{~min}$ at $4^{\circ} \mathrm{C}$, and the pellet containing the hepatocytes was treated with $1.0 \mathrm{~mL}$ of ice-cold $1 \mathrm{M} \mathrm{HClO}_{4}$. After centrifugation at $2000 \mathrm{~g}$ for $10 \mathrm{~min}$ at $4^{\circ} \mathrm{C}$, aliquots $(100 \mu \mathrm{L})$ of the supernatant were neutralized with $65 \mu \mathrm{L}$ of $2 \mathrm{M} \mathrm{KOH}$; suspended in $100 \mathrm{mM}$ Tris- $\mathrm{HCl}, \mathrm{pH} 7.8$ (1.0 mL final volume), and centrifuged again. Bioluminescence was measured in the supernatant with a Sigma-Aldrich assay kit according to the manufacturer's instructions using a SIRIUS Luminometer (Berthold, Pforzheim, Germany).

\section{Intracellular $\mathrm{Ca}^{2+}$ homeostasis}

Hepatocytes $\left(2 \times 10^{6} \mathrm{~mL}^{-1}\right)$ were incubated in the Krebs-Henseleit medium that was supplemented with $2 \%$ BSA, $12.5 \mathrm{mM}$ HEPES and $10 \mathrm{mM}$ glucose, $\mathrm{pH}$ 7.4. In this medium, $0.005 \%$ pluronic acid and $5 \mu \mathrm{M}$ Fura-2 acetoxymethyl ester (Fura-2 AM) were added. The hepatocytes were maintained under constant agitation at $32^{\circ} \mathrm{C}$ for 60 min to capture the probe. The cell suspension that was loaded with Fura-2 AM was collected and subjected to two centrifugations at $50 \mathrm{~g}$ for $3 \mathrm{~min}$ to remove the residual Fura-2 AM and maintained at $4^{\circ} \mathrm{C}$ for later use. The fluorescence of $\mathrm{Ca}^{2+}$ was determined by the ratio of the excitation wavelengths at 340 and $380 \mathrm{~nm}$ and emission wavelength at $505 \mathrm{~nm}$ using the fluorescence spectrophotometer RF-5301 PC (Shimadzu, Tokyo, Japan). The calibration and calculations in $\left[\mathrm{Ca}^{2+}\right]_{\mathrm{c}}$ were performed as previously described (Grynkiewicz et al. 1985). The maximum fluorescence $\left(\mathrm{F}_{\max }\right)$ was obtained by the addition of $1 \%$ Triton X-100, and the minimum fluorescence $\left(\mathrm{F}_{\mathrm{min}}\right)$ was obtained by the addition of $10 \mathrm{mM}$ EGTA. The equilibrium constant for the calculations was $225 \mathrm{nM}$. Changes in free $\left[\mathrm{Ca}^{2+}\right]_{\mathrm{c}}$ in the cytoplasm of hepatocytes were evaluated with increasing additions of fipronil (25, $50,75$ and $100 \mu \mathrm{M})$ every 300 seconds. A positive control to establish the maximum increase in the intracellular $\mathrm{Ca}^{2+}$ concentration was performed using the ionophore ionomycin. 


\section{Evaluation of cell viability}

The cell viability was assessed by trypan blue uptake and the release of alanine transaminase (ALT) and aspartate transaminase (AST) from hepatocytes. After incubation with fipronil at concentrations of $25,50,75$ and $100 \mu \mathrm{M}$, the cell suspensions were collected at $0,30,60,90$ and $120 \mathrm{~min}$. The hepatocyte suspension was incubated with $0.16 \%$ trypan blue solution for 3 min at room temperature. Trypan blue-positive cells were counted in four different fields $(\times 10)$. For ALT and AST release measurements, the hepatocyte suspension was centrifuged (50 $g$ for 5 $\mathrm{min}$ ), and the presence of the enzymes in the supernatant was determined using Enzyme Activity Assay Kits (Bioclin, Quibasa, Brazil) according to the manufacturer's instructions. The absorbance was measured at $340 \mathrm{~nm}$ with a spectrophotometer DU-800 (Beckman Coulter, Fullerton, CA, USA). The enzyme activity in the supernatant was expressed as the percentage of the total activity, which was determined by lysing the cells with $0.5 \%$ Triton X-100.

\section{Statistical analysis}

The data are expressed as the mean \pm standard error of the mean (S.E.M.). The statistical significance of the differences between the control and experimental groups was evaluated using a one-way analysis of variance (ANOVA) followed by Dunnett's test. Values of $P<0.05$ were considered significant. All of the statistical analyses were performed using the GraphPad Prism software, version 4.0 for Windows (GraphPad Software, San Diego, CA, USA).

\section{RESULTS}

Effects of fipronil on the respiration of mitochondria in isolated rat hepatocytes

Figures 1 shows the inhibitory effect of fipronil on the glutamate-plus-malate-supported state 3 (ADP-stimulated) respiration of mitochondria in digitonin-permeabilized hepatocytes. Fipronil showed an inhibitory action in a concentrationdependent manner beginning at $25 \mu \mathrm{M}$. Fipronil neither presented an inhibitory effect on the succinate-supported state 3 nor stimulated state 4 (basal) respiration (results not shown). These results indicated that fipronil inhibited the respiratory chain complex I of mitochondria as assessed in isolated hepatocytes. These results agreed with those previously described that showed fipronil as an inhibitor of the complex I in isolated mitochondria (Tavares et al. 2015).

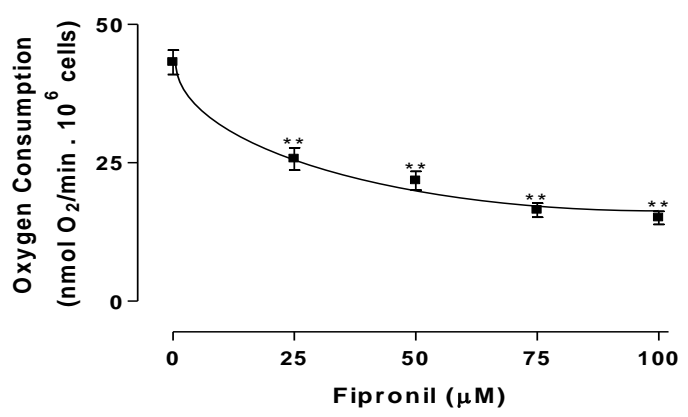

Figure 1 - Effects of fipronil on the glutamate-plusmalate-supported state 3 (ADP-stimulated) respiration of mitochondria in digitoninpermeabilized isolated rat hepatocytes. The results represent the mean \pm SEM of five experiments with different cell preparations. ${ }^{* *}$ Significantly different from the control (without fipronil) $(\mathrm{P}<0.01)$.

Effects of fipronil on the mitochondrial membrane potential in isolated rat hepatocytes

The effects of fipronil on the mitochondrial membrane potential in digitonin-permeabilized hepatocytes energized with glutamate-plus-malate are shown in Figure 2. The addition of increasing concentrations of fipronil to the hepatocytes (25 to $100 \mu \mathrm{M})$ resulted in a decrease in the mitochondrial membrane potential in a concentration-dependent manner as observed in respiration experiments.

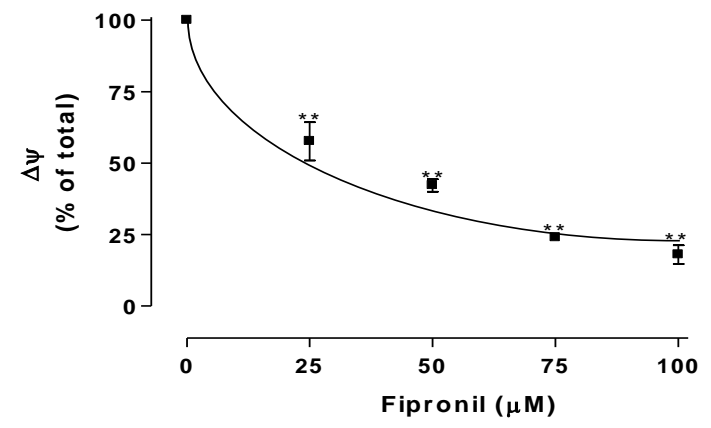

Figure 2 - Effects of fipronil on the mitochondrial membrane potential as assessed by the uptake of the fluorescent probe rhodamine 123 in isolated rat hepatocytes $\left(10^{6}\right.$ cells $\mathrm{mL}^{-}$ $\left.{ }^{1}\right)$. The results represent the mean \pm SEM of five experiments with different cell preparations. ${ }^{* *}$ Significantly different from the control (without fipronil) $(\mathrm{P}<0.01)$. 
Effects of fipronil on the mitochondrial ATP levels in isolated rat hepatocytes

The effects of fipronil on the mitochondrial ATP levels were evaluated in the hepatocytes that were isolated from normal and proadifen-pretreated rats (Fig. 3). The addition of increasing concentrations of fipronil ( 25 to $100 \mu \mathrm{M})$ to the hepatocytes that were isolated from normal rats resulted in a decrease in the mitochondrial ATP levels in a concentration- and time-dependent manner. At 25 $\mu \mathrm{M}$ fipronil, a significant reduction in the ATP levels was observed at $120 \mathrm{~min}$ from the beginning of the experimental period. There was a significant reduction in the ATP levels after 30 min at concentrations of 50,75 and $100 \mu \mathrm{M}$ fipronil.

Proadifen stimulated a fipronil-induced decrease in the ATP levels because the cells that were isolated from proadifen-pretreated rats presented a significant decrease in ATP levels already at 60 min of the experimental period at lower concentrations of fipronil $(25 \mu \mathrm{M})$. In the other fipronil concentrations that were tested $(50,75$ and $100 \mu \mathrm{M}$ ), the intracellular ATP levels were significantly reduced already at $30 \mathrm{~min}$, as observed in the hepatocytes that were isolated from normal rats.

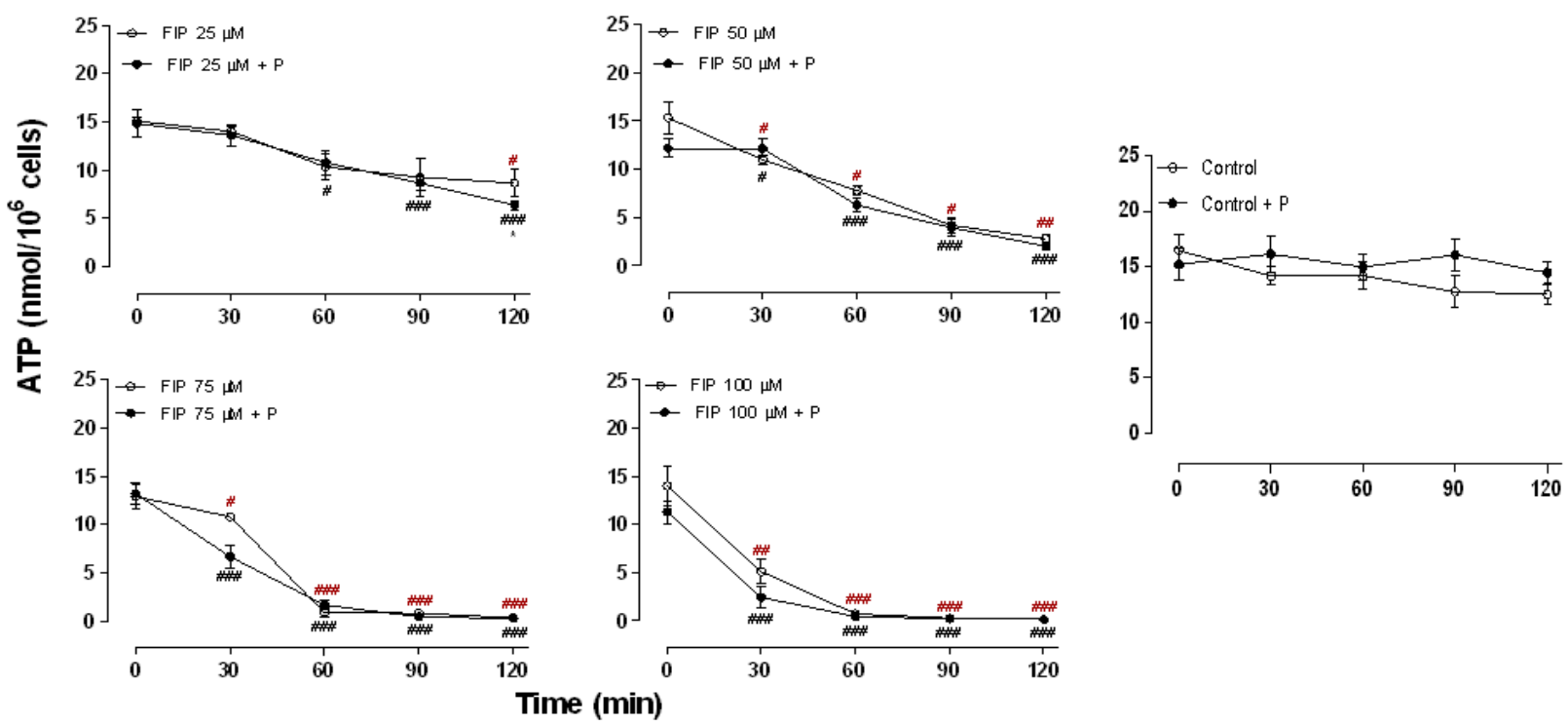

Figure 3 - Effects of fipronil on the intracellular concentration of ATP in isolated rat hepatocytes $\left(10^{6}\right.$ cells $\left.\mathrm{mL}^{-1}\right)$ in the absence or presence of proadifen $(\mathrm{P})$. The results represent the mean \pm SEM of six different cell preparations. "\#\# Significantly different from the control (without fipronil) at the corresponding time $\left(\mathrm{P}<0.05\right.$ and $\mathrm{P}<0.01$, respectively). ${ }^{*, * * *}$ Significantly different from "without proadifen" at the corresponding time $(\mathrm{P}<0.05$ and $\mathrm{P}<0.01$, respectively). ("without proadifen).

Effects of fipronil on intracellular $\mathrm{Ca}^{2+}$ homeostasis in isolated rat hepatocytes

Intracellular $\mathrm{Ca}^{2+}$ homeostasis was evaluated by the changes in the fluorescence probe Fura-2 in hepatocytes that were exposed to increasing concentrations of fipronil $(25$ to $100 \mu \mathrm{M})$ in the absence of proadifen (Fig. 4). The cytosolic $\mathrm{Ca}^{2+}$ concentration increased after the addition of 25 and $50 \mu \mathrm{M}$ fipronil and did not change following the addition of higher concentrations (75 and 100 $\mu \mathrm{M})$ of the insecticide.

\section{Effects of fipronil on cell viability in isolated rat hepatocytes}

The evaluation of trypan blue uptake as an indicator of cell viability showed a significant increase in cell membrane permeability up to 60 min after exposure to $100 \mu \mathrm{M}$ fipronil (Fig. 5). At $120 \mathrm{~min}$, approximately $90 \%$ of the cells were trypan-blue-positive. The release of ALT (Fig. 6) and AST (Fig. 7) was used to monitor the viability in the hepatocytes that were isolated from normal or proadifen-pretreated rats.

The addition of increasing concentrations of fipronil to hepatocytes resulted in decreased cell viability, as assessed by ALT and AST leakage into the incubation medium, in a concentrationand time-dependent manner (Figs. 6 and 7, 
respectively). A significant increase in the concentration of ALT in the supernatant of hepatocytes that were isolated from normal rats was observed at $60 \mathrm{~min}$ with $50 \mu \mathrm{M}$ fipronil, and the AST concentration increased at 90 min with 50 $\mu \mathrm{M}$ fipronil.

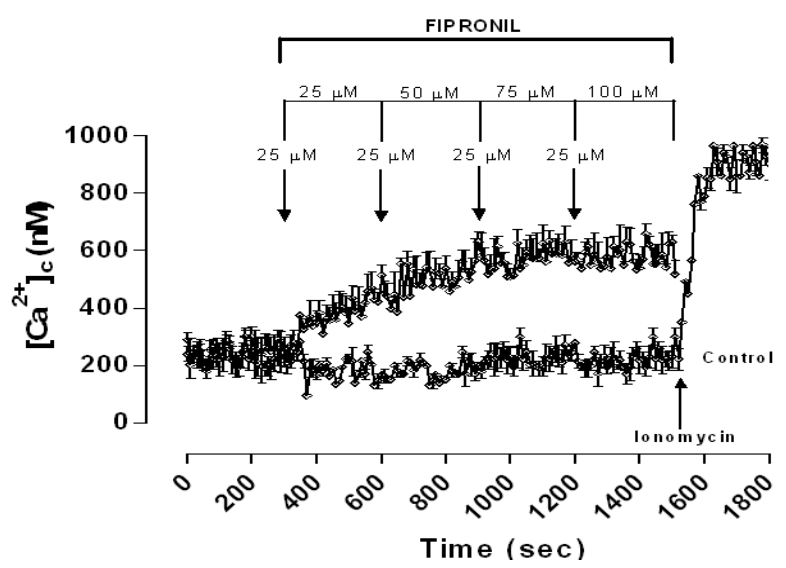

Figure 4-Effects of fipronil on intracellular $\mathrm{Ca}^{2+}$ homeostasis in isolated rat hepatocytes $(2 \times$ $10^{6}$ cells $\left.\mathrm{mL}^{-1}\right)$ that were permeabilized with pluronic acid $(0.005 \%)$. The results represent the mean \pm SEM of six experiments with different cell preparations. Control: without fipronil; Positive control: Ionomycin $20 \mu \mathrm{M}$.
The pretreatment of rats with proadifen inhibited the effect of fipronil on ALT release because a significant increase in the concentration of the enzyme in the supernatant was observed only at 90 min with $50 \mu \mathrm{M}$ fipronil (Fig. 6). The effect of fipronil in the AST release was not changed (Fig. 7).

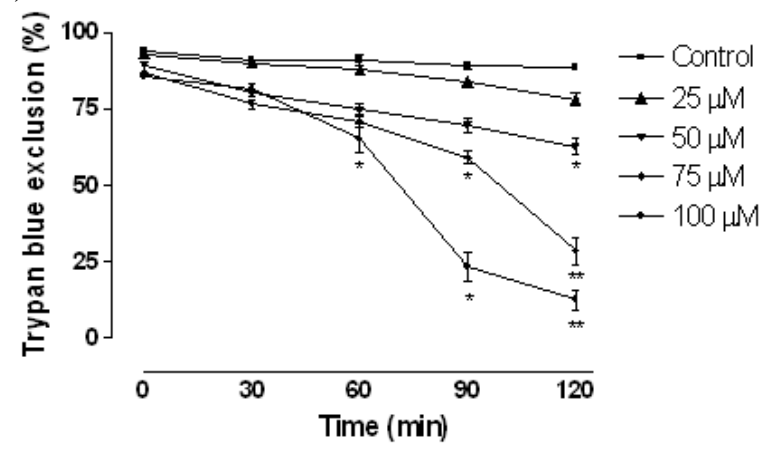

Figure 5 - Time course of cell injury as indicated by trypan blue exclusion in isolated rat hepatocytes $\left(10^{6}\right.$ cells $\left.\mathrm{mL}^{-1}\right)$. The percent of viable (trypan blue-negative) cells is shown for each time point. The results represent the mean \pm SEM of six experiments with different cell preparations. ${ }^{* * *}$ Significantly different from the control (without fipronil) at the corresponding time $(\mathrm{P}<0.05$ and $\mathrm{P}<$ 0.01 , respectively).
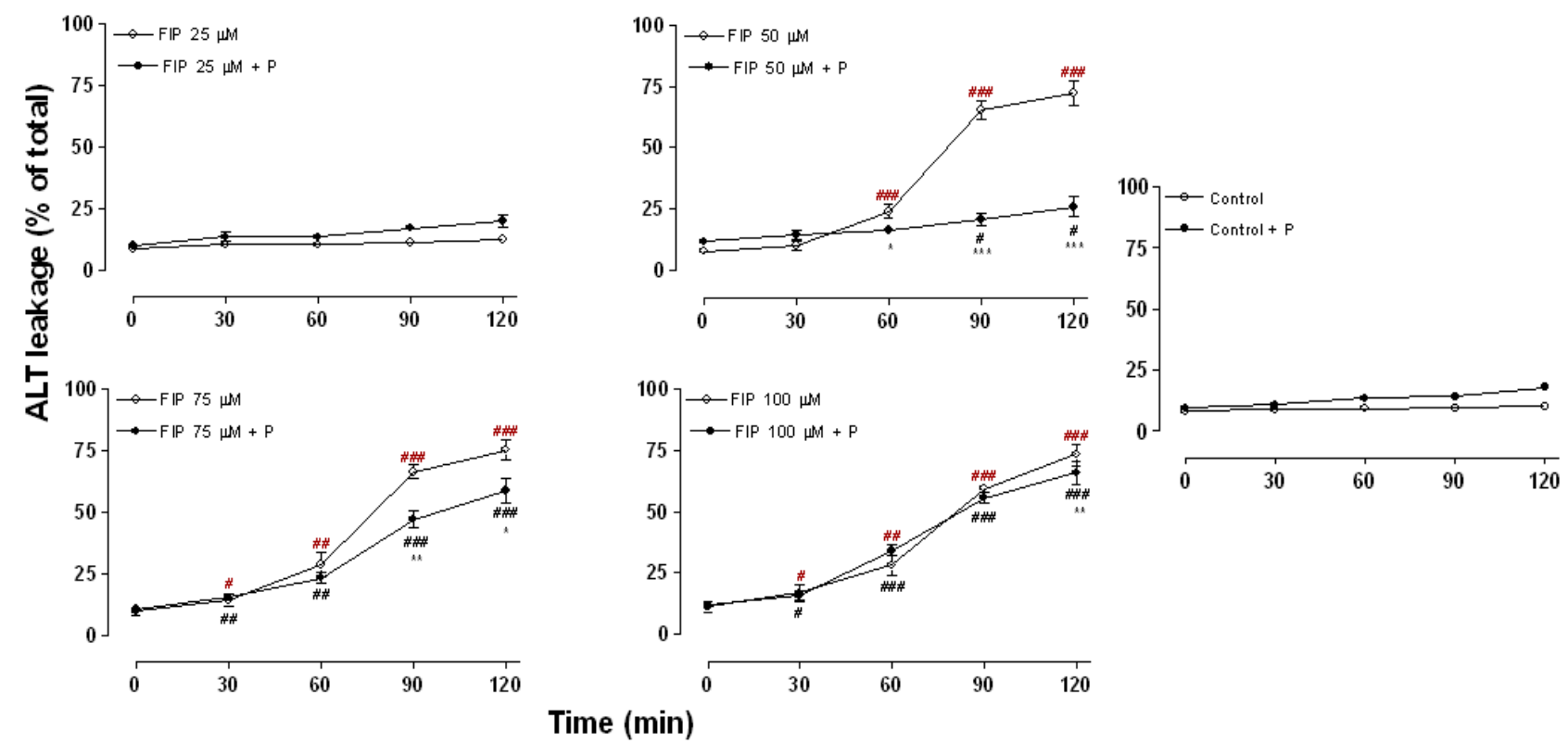

Time (min)

Figure 6 - Effects of fipronil on the cell viability as assessed by the release of the enzyme alanine transaminase (ALT) in isolated rat hepatocytes $\left(10^{6}\right.$ cells $\left.\mathrm{mL}^{-1}\right)$ in the absence or presence of proadifen $(\mathrm{P})$. The results represent the mean \pm SEM of six experiments with different cell

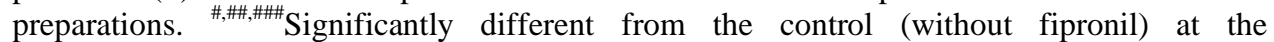
corresponding time $\left(\mathrm{P}<0.05, \mathrm{P}<0.01\right.$ and $\mathrm{P}<0.001$, respectively). ${ }^{*, * *, * * * *}$ Significantly different from "without proadifen" at the corresponding time $(\mathrm{P}<0.05, \mathrm{P}<0.01$ and $\mathrm{P}<$ 0.001 , respectively). ( $"$ without proadifen). 


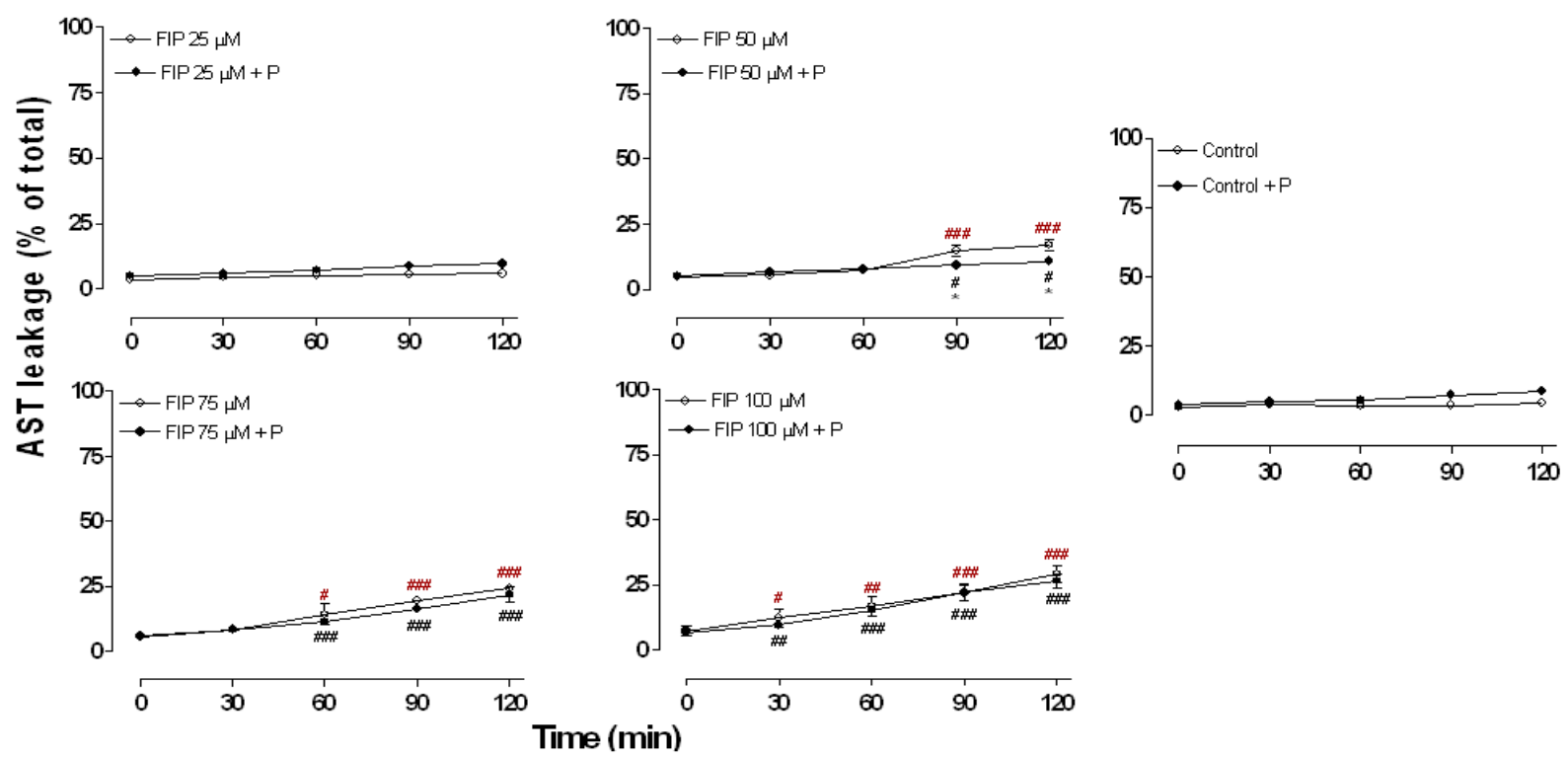

Figure 7 - Effects of fipronil on the cell viability as assessed by the release of the enzyme aspartate transaminase (AST) in isolated rat hepatocytes $\left(10^{6}\right.$ cells $\left.\mathrm{mL}^{-1}\right)$ in the absence or presence of proadifen $(\mathrm{P})$. The results represent the mean \pm SEM of six experiments with different cell preparations. \#,\#,\#\# Significantly different from the control (without fipronil) at the corresponding time $\left(\mathrm{P}<0.05, \mathrm{P}<0.01\right.$ and $\mathrm{P}<0.001$, respectively). ${ }^{*, * *, * * * *}$ Significantly different from "without proadifen" at the corresponding time $(\mathrm{P}<0.05, \mathrm{P}<0.01$ and $\mathrm{P}<$ 0.001 , respectively). ("without proadifen).

\section{DISCUSSION}

The results presented in this study demonstrated that fipronil reduced cellular respiration in the cells that were energized with glutamate plus malate in a dose-dependent manner and decreased the mitochondrial membrane potential, followed by a reduction in the concentration of ATP and cell viability, in addition to altering the intracellular homeostasis $\mathrm{Ca}^{2+}$.

Studies of the effects of fipronil on the cells indicated that this insecticide induced cell death by apoptosis. Liver cells that were exposed to low concentrations of fipronil $(0.1 \mathrm{mM})$, in addition to decreasing the ATP, experienced the activation of enzymes that participate in the process of apoptosis, i.e., caspase 3 and 7 (Das et al. 2006). Histological studies also demonstrated the disorganized and modified cell nucleus of hepatocytes, with chromatin condensation and marginalization, indicating the occurrence of apoptosis (Ferreira et al. 2012).

During the biotransformation of xenobiotics in the liver, the generated metabolites may be more toxic than the parent compound (Ioannides and Lewis
2004). Fipronil in mammalian liver is metabolized primarily into fipronil-sulfone, and as result of photodegradation, which may occur in the soil or in water, the major metabolite is fipronildesulfinyl, both of which are less selective for GABA receptors but more persistent and toxic to insects, mammals, fish and birds compared with the parent compound (Das et al. 2006). Tang et al. (2004) reported that the CYP3A4 isoform was primarily responsible for the hepatic metabolism of fipronil in humans. Therefore, to evaluate the effect of biotransformation on the toxicity of fipronil, some experiments were performed using hepatocytes that were isolated from the rats that were pretreated with proadifen, a classic inhibitor of cytochrome P450 (Anders and Mannering 1996; Bort et al. 1998; Mingatto et al. 2002; Somchit et al. 2009).

The interference of fipronil in the functioning of the mitochondrial electron transport chain in the isolated rat hepatocytes was monitored by measuring the oxygen consumption. The results showed a clear inhibition of the complex I of the electron transport chain by the insecticide because a decrease in the oxygen consumption rate in the 
state 3 respiration of cells that were energized with glutamate plus malate substrates at concentrations of 25 to $100 \mu \mathrm{M}$ was observed. Fipronil also affected the mitochondrial membrane potential of hepatocytes in a dose-dependent manner. These results agreed with those obtained by Tavares et al. (2015), who evaluated the effects of fipronil on the isolated mitochondria of rat liver.

By inhibiting the electron transport chain and the formation of the mitochondrial membrane potential, it would be expected that fipronil reduced the intracellular concentration of ATP. In fact, this effect was previously observed in different cell models (Das et al. 2006; Vidau et al. 2009; Vidau et al. 2011). In the present study, a reduction in ATP concentration was observed in the hepatocytes that were isolated from both normal and proadifen-pretreated rats, which indicated that the biotransformation did not alter its toxicity, as previously shown by Das et al. (2006). This observed reduction in the ATP concentration could be enough to reduce the efficiency of energy-dependent processes and the transduction of cellular signals that were mediated by the ATP, which, according to Eguchi et al. (1997) and Skulachev (2006), could lead to cell death.

When hepatocytes were exposed to fipronil, an increase in cytosolic $\mathrm{Ca}^{2+}$ occurred. This effect could be a result of the release of mitochondrial calcium as observed in the studies that were conducted using isolated rat liver mitochondria (Tavares et al. 2015). Another hypothesis was that the fipronil-induced mitochondrial dysfunction reducing cellular ATP levels could (in organelles such as the endoplasmic reticulum) promote the inactivation of the pump that was responsible for the maintenance of the ion gradient in the cytoplasm (Thastrup et al. 1990; Lytton et al. 1991). In addition, the permeabilization of plasma membrane caused by fipronil, as showed by ALT and AST data, could also contribute to the increase in intracellular $\mathrm{Ca}^{2+}$ level. This increased cytosolic $\mathrm{Ca}^{2+}$ can lead to activation of proteases, phospholipases and ion-dependent endonucleases (Trump and Berzesky 1992). The activation of proteases and phospholipases induces changes in the cytoskeleton and plasma membrane. When combined, these processes culminate in the disruption of cytoskeleton-plasma membrane interactions, which results in the destabilization of the lipid bilayer, bleb formation on the cell surface and, in more severe cases, leakage and cellular necrosis (Nicotera et al. 1986; Gores et al. 1990; Sakaida et al. 1992).

The trypan blue dye exclusion test showed a decrease in cell viability with increasing incubation time and concentration of the insecticide. This test measures the permeability of the plasma membrane and can be used as an indicator of cell necrosis (Freshney 1994).

The effect of fipronil on the viability of hepatocytes was also assessed by the activity of the enzymes ALT and AST. AST is an enzyme that is found mostly in mitochondria, approximately $80 \%$, and it is not released as fast as ALT, which is purely a cytosolic enzyme. AST is found in high concentrations in a number of tissues, such as the heart, liver, skeletal muscle, kidney and pancreas. ALT is primarily limited to the cytosol of hepatocytes, is considered a highly sensitive indicator of hepatocellular damage and, within certain limits, can provide a quantitative ratio of the degree of damage that is suffered by the liver (Al-Habori et al. 2002).

Present results showed there was an increase in the release of the enzymes ALT and AST in the incubation liquid of hepatocytes, which, according to Grisham (1984), indicated a loss of membrane integrity that was associated with the death or lysis of cells or even some reversible changes that resulted in increased permeability (Grishan and Smith 1984). The pretreatment of the animals with proadifen, an inhibitor of cytochrome P450, altered the release of ALT as promoted by fipronil at a concentration of $50 \mu \mathrm{M}$, indicating that the biotransformation of insecticide enhanced its toxic effect. Therefore, the results of cell viability in the present study agreed with those that were obtained by Das et al. (2006), who assessed the effects of fipronil and its metabolite sulfone on the cell viability of HepG2 cells and human hepatocytes.

Among the types of cell death are necrosis and apoptosis, and there is currently no doubt that apoptosis requires energy to occur because it is regulated by numerous stages that are dependent on ATP, such as the activation of caspases, enzymatic hydrolysis of macromolecules, chromatin condensation, formation of bubbles on the surface of the plasma membrane and formation of apoptotic bodies (Kass et al. 1996; Barros et al. 2003). Necrosis, however, is characterized by the alterations that cause the total depletion of ATP, disruption of ionic balance, cellular and mitochondrial swelling, and activation of degradative enzymes, resulting in the disruption of 
the plasma membrane, loss of proteins, metabolites and intracellular ions (Eguchi et al. 1997; Nicotera et al. 1998; Lemasters et al. 1999). According Vidau et al. (2009) fipronil induces cytotoxic effects in Caco- 2 cells from the intestinal epithelium. The reduction of cohesive properties of epithelial cells has been attributed to a decrease in ATP concentrations. Moreover, chronic exposure to fipronil and its metabolites (sulfone and sulfide) triggers cell death.

Due to the aspects that were presented by the cells death by necrosis, as described by Eguchi et al. (1997), it was reasonable to assume that fipronil triggered the process of necrosis in hepatocytes due to the drastic reduction in ATP synthesis, but apoptosis could not be ruled out. Accordingly, Das et al. (2006), using human hepatoma cells (HepG2) and human hepatocytes, and Vidau et al. (2011), using human neuroblastoma cells (SHSY5Y), demonstrated that fipronil induced cell death by apoptosis.

\section{CONCLUSION}

The results in this study suggested that the mechanism of fipronil hepatotoxicity involved an effect on mitochondrial bioenergetics and an alteration in calcium homeostasis, which led to a decrease in ATP synthesis with consequent cell death by necrosis. This study also showed that the metabolism of fipronil, which was performed by cytochrome $\mathrm{P} 450$ in the liver, influenced its toxicity because there was a decrease in the toxic potential of fipronil in the presence of proadifen, which indicated that the metabolites had greater potential than that of the parent compound. These results contributed to the understanding of the toxicity caused by fipronil in the liver.

\section{ACKNOWLEDGEMENTS}

This work was supported by grants from Fundação de Amparo à Pesquisa do Estado de São Paulo (FAPESP), Processes numbers 2012/15135-6 and 2012/24872-4, Brazil.

\section{REFERENCES}

Aajoud A, Ravanel P, Tissut M. Fipronil metabolism and dissipation in a simplified aquatic ecosystem. $J$ Agr Food Chem. 2003; 51: 1347-1352.

Al-Habori M. Toxicological evaluation of Catha edulis leaves: a long term feeding experiment in animals. $J$ Ethnopharmacol. 2002; 83: 209-217.

Anders MW, Mannering GJ. Inhibition of drug metabolism: kinetics of the inhibition of the $\mathrm{N}$ demethylation of ethylmorphine by 2diethylaminoethyl 2,2-diphenylvalerate $\mathrm{HCl}$ (SKF 525-A) and related compounds. Mol Pharmacol. 1966; 2: 319-327.

Barros LF, Kanaseki T, Sabirov R, Morishima S, Castro J, Bittner CX, et al. Apoptotic and necrotic blebs in epithelial cells display similar neck diameters but different kinase dependency. Cell Death Differ. 2003; 10: 687-697.

Bobe A, Coste CM, Cooper JF. Factors influencing the adsorption of fipronil on soils. J Agr Food Chem. 1997; 45: 4861-4865.

Bort R. Diclofenac toxicity to hepatocytes: a role for drug metabolism in cell toxicity. J Pharmacol Exp Ther. 1998; 288: 65-72.

Caboni P, Sammelson RE, Casida JE. Phenylpyrazole insecticide photochemistry, metabolism, and GABAergic action: ethiprole compared with fipronil. J Agric Food Chem. 2003; 51: 7055-7061.

Chaton PF, Ravanel P, Tissut M, Meyran JC. Toxicity and bioaccumulation of fipronil in the nontarget arthropodan fauna associated with subalpine mosquito breeding. Ecotoxicol Environ Saf. 2002; 52: 8-12.

Chodorowski Z, Anand JS. Accidental dermal and inhalation exposure with fipronil - a case report. $J$ Toxicol. 2004; 42(2): 189-190.

Das PC, Cao Y, Cherrington N, Hodgson E, Rose RL. Fipronil induces CYP isoforms and cytotoxicity in human hepatocytes. Chem-Biol Interact. 2006; 164: 200-214.

Eguchi Y, Shimizu S, Tsujimoto Y. Intracellular ATP levels determine cell death fate by apoptosis or necrosis. Cancer Res. 1997; 57: 1835-1840.

Ferreira M, Oliveira PR, Denardi SE, Bechara GH, Mathias MIC. Action of the chemical agent fipronil (active ingredient of acaricide frontline) on the liver of mice: an ultrastructural analysis. Microsc Res Techniq. 2012; 75: 197-205.

Freshney RI. Culture of Animal Cells. A Manual of Basic Technique. 3. ed. New York: Wiley-Liss; 1994. 486p. 
Fung HT, Chan KK, Ching WM, Kam CW. A case of accidental ingestion of ant bait containing fipronil. $J$ Toxicol-Clin Toxic. 2003; 41(3): 245-248.

Gores GJ, Herman B, Lemasters JJ. Plasma membrane bleb formation and rupture: a common feature of hepatocellular injury. Hepatology. 1990; 11: 690698.

Grisham JW, Smith GJ. Predictive and mechanistic evaluation of toxic responses in mammalian cell culture systems. Pharmacol Rev. 1984; 36: 151S$171 \mathrm{~S}$.

Grynkiewicz G, Poenie M, Tsien RY. A new generation of $\mathrm{Ca}^{2+}$ indicators with greatly improved fluorescence properties. J Biol Chem. 1985; 260: 3440-3450.

Guguen-Guillouzo C. Isolation and culture of animal and human hepatocytes. In: Freshney RI, editor. Culture of Epithelial Cells. New York: Wiley-Liss; 1992. p. 197-223.

Guillouzo A. Liver cell models in in vitro toxicology. Environ Health Perspect. 1998; 106: 511-532.

Hainzl D, Casida JE. Fipronil insecticide: novel photochemical desulfinylation with retention of neurotoxicity. Proc Natl Acad Sci. 1996; 93: 1274612767.

Ioannides C, Lewis DFV. Cytochromes P450 in the bioactivation of chemicals. Curr Top Med Chem. 2004; 4: 1767-1788.

Jennings KA, Canerdy TD, Keller RJ, Atieh BH, Doss RB, Gupta RC. Human exposure to fipronil from dogs treated with frontline. Vet Hum Toxicol. 2002; 44(5): 301-303.

Kass GEN, Eriksson JE, Weis M, Orrenius S, Chow SC. Cromatin condensation during apoptosis requires ATP. Biochem J. 1996; 318: 749-752.

Lee SJ, Mulay P, Diebolt-Brown B, Lackovic MJ, Mehler LN, Beckman J, et al. Acute illnesses associated with exposure to fipronil - surveillance data from 11 states in the United States, 2001-2007. Clin Toxicol. 2010; 48(7): 737-744.

Leghait J, Gayrard V, Picard-Hagen N. Fipronilinduced disruption of thyroid function in rats is mediated by increased total and free thyroxine clearances concomitantly to increased activity of hepatic enzymes. Toxicology. 2009; 255: 38-44.

Lemasters JJ, Diguiseppi J, Nieminen AL, Herman B. Blebbing, free $\mathrm{Ca}^{2+}$ and mitochondrial membrane potential preceding cell death in hepatocytes. Nature. 1987; 325: 78-81.

Lemasters JJ, Qian T, Bradham CA, Brenner DA, Cascio WE, Trost LC, et al. Mitochondrial dysfunction in the pathogenesis of necrotic and apoptotic cell death. J Bioenerg Biomembr. 1999; 31: 305-319.

Lytton J, Westlin M, Hanley MR. Thapsigargin inhibits the sarcoplasmic or endoplasmic reticulum $\mathrm{Ca}$ ATPase family of calcium pumps. J Biol Chem. 1991; 266(26): 17067-17071.
Maioli MA, Alves LC, Perandin D, Garcia AF, Pereira FTV, Mingatto FE. Cytotoxicity of monocrotaline in isolated rat hepatocytes: Effects of dithiothreitol and fructose. Toxicon. 2011; 57: 1057-1064.

Meyer SA, Kulkarni AP. Hepatotoxicity. In: Hodgson E, Smart RC, editors. Introduction to Biochemical Toxicology. 3. ed. New York: John Wiley \& Sons; 2001. p. 487-507.

Mingatto FE, Rodrigues T, Pigoso AA, Uyemura SA, Curti C, Santos AC. The critical role of mitochondrial energetic impairment in the toxicity of nimesulide to hepatocytes. J Pharmacol Exp Ther. 2002; 303: 601607.

Mingatto FE, Dorta DJ, Dos Santos AB, Carvalho I, Da Silva CH, Da Silva VB, et al. Dehydromonocrotaline inhibits mitochondrial complex I. A potential mechanism accounting for hepatotoxicity of monocrotaline. Toxicon. 2007; 50: 724-730.

Mohamed F, Senarathna L, Percy A, Abeyewardene M, Eagleshmam G, Cheng R, et al. Acute human poisoning with the N-phenylpyrazole 27 insecticide fipronil - a $\mathrm{GABA}_{\mathrm{A}}$ - gated chloride channel blocker. J Toxicol-Clin Toxic. 2004; 42(7): 955-963.

Moreadith RW, Fisckum G. Isolation of mitochondria from ascites tumor cells permeabilized with digitonin. Anal Biochem. 1984; 137: 360-367.

Nicotera P, Leist M, Ferrando-Mey E. The formation of plasma membrane blebs in hepatocytes exposed to agents that increase cytosolic $\mathrm{Ca}^{2+}$ is mediated by the activation of a nonlysosomal proteolytic system. FEBS Lett. 1986; 209: 139-144.

Nicotera P, Leist M, Ferrando-Mey E. Intracellular ATP, a switch in the decision between apoptosis and necrosis. Toxicol Lett. 1998; 102-103: 139-142.

Oga S. Fundamentos de toxicologia. 3. ed. São Paulo: Atheneu; 2008. 677p.

Oliveira PR, Bechara GH, Denardi SE, Oliveira RJ, Mathias MIC. Cytotoxicity of fipronil on mice liver cells. Microsc Res Techniq. 2012; 75(1): 28-35.

Sakaida I, Thomas AP, Farber JL. Phospholipid metabolism and intracelular $\mathrm{Ca}^{2+}$ homeostasis in cultured rat hepatocytes intoxicated with cyanide. $\mathrm{Am}$ J Physiol. 1992; 263: C684-C690.

Silva AS. Neurobehavioral effects of fipronil long term exposure in rats. University of São Paulo: Faculty of Pharmaceutical Sciences. Master's Dissertation; 2008. 108p.

Skulachev VP. Bioenergetic aspects of apoptosis, necrosis and mitoptosis. Apoptosis. 2006; 11: 473485.

Somchit N, Ngee CS, Yaakob A, Ahmad Z, Zakaria ZA. Effects of cytochrome P450 inhibitors on itraconazole and fluconazole induced cytotoxicity in hepatocytes. J Toxicol. 2009; 2009: 1-7.

Tang J, Amin Usmani K, Hodgson E, Rose RL. In vitro metabolism of fipronil by human and rat cytochrome $\mathrm{P} 450$ and its interactions with testosterone and diazepam. Chem-Biol Interact. 2004; 147: 319-329. 
Tavares MA, Palma IDF, Medeiros HC, Guelfi M, Santana AT, Mingatto FE. Comparative effects of fipronil and its metabolites sulfone and desulfinyl on the isolated rat liver mitochondria. Environ Toxicol Pharmacol. 2015; 40(1): 206-214.

Thastrup O, Cullen PJ, Drøbak BK, Hanley MR, Dawson AP. Thapsigargin, a tumor promoter, discharges intracellular $\mathrm{Ca}^{2+}$ stores by specific inhibition of the endoplasmic reticulum $\mathrm{Ca}^{2+}$-ATPase. Proc Natl Acad Sci. 1990; 87(7): 2466-2470.

Tingle CC, Rother JA, Dewhurst CF, Lauer S, King WJ. Fipronil: environmental fate, ecotoxicology, and human health concerns. Rev Environ Contam Toxicol. 2003; 176: 1-66.

Trump BF, Berzesky IK. The role of cytosolic $\mathrm{Ca}^{2+}$ in cell injury, necrosis and apoptosis. Curr Opin Cell Biol. 1992; 4: 227-232.
Vidau C, Brunet JL, Badiou A, Belzunces LP. Phenylpyrazole insecticides induce cytotoxicity by altering mechanisms involved in cellular energy supply in the human epithelial cell model Caco-2. Toxicol in Vitro. 2009; 23: 589-597.

Vidau C, González-Polo RA, Niso-Santano M, GomézSánchez R, Bravo-San Pedro JM, Pizarro-Estrella E, et al. Fipronil is a powerful uncoupler of oxidative phosphorylation that triggers apoptosis in human neuronal cell line SHSY5Y. Neurotoxicology. 2011; 32: 935-943.

Zhao X, Yeh JZ, Salgado VL, Narahashi T. Fipronil is a potent open channel blocker of glutamate-activated chloride channels in cockroach neurons. Pharmacol Exper Therap. 2004; 310(1): 192-201. 